\title{
Maxillary Ameloblastic Fibroma: A Case Report
}

\author{
Daniela Otero Pereira da COSTA ${ }^{1}$ \\ Adriana Terezinha Neves Novellino ALVES ${ }^{2}$ \\ Mônica Diuna CALASANS-MAIA ${ }^{1}$ \\ Ricardo Lopes da CRUZ 3 \\ Simone de Queiroz Chaves LOURENÇO ${ }^{1}$
}

\author{
${ }^{1}$ Department of Pathology, UFF - Fluminense Federal University, Niterói, RJ, Brazil \\ ${ }^{2}$ Dental School, Discipline of Oral Pathology, University Gama Filho, Rio de Janeiro, RJ, Brazil \\ ${ }^{3}$ Department of Oral and Maxillofacial Surgery, INTO - Institute of Orthopedics and Trauma, Rio de Janeiro, RJ, Brazil
}

\begin{abstract}
Ameloblastic fibroma is a relatively rare benign odontogenic tumor in which both the epithelial and ectomesenchymal components are neoplastic. An 8-year-old Caucasian boy was referred to the dentist for evaluation of failed eruption of the maxillary left first molar. The panoramic radiograph showed a well-circumscribed unilocular radiolucency involving an unerupted maxillary left first permanent molar. The lesion was enucleated and the material was sent for histopathologic examination. Microscopically, it was composed by cords and islands of odontogenic epithelium in a myxoid cell-rich stroma that closely resemble the dental papilla with histopathological diagnosis of ameloblastic fibroma. After 24 months of follow-up no recurrence was observed and the maxillary left first molar erupted spontaneously through the buccal mucosa and was aligned with a fixed orthodontic appliance. This case emphasized the importance of careful differential diagnosis of intraosseous oral lesions and reported a rarity of the lesion and its atypical location.
\end{abstract}

Key Words: ameloblastic fibroma, odontogenic tumor, maxillary tumor.

\section{INTRODUCTION}

Ameloblastic fibroma (AF) is a benign odontogenic tumor considered a true mixed tumor composed of neoplastic epithelium and mesenchymal (1). This tumor is rare, representing only $2 \%$ of all odontogenic tumors (1-5).

AF has been reported in patients aged 7 weeks to 51 years $(6,7)$, but the tumor is considered a tumor of childhood and adolescence and occur almost exclusively in the first and second decades of life (6,8-13). In the majority of cases, the lesion arises in the mandible and patients present as a slow-growing, painless lesion and/or failure of the tooth eruption (8-12). However, the tooth impaction and delayed eruption may be associated with dental developmental defects or abnormalities such as amelogenesis imperfecta (14). In other cases, the tumors are asymptomatic and discovered during routine oral/ radiographic examination (12).

Radiographically, AF appears as well-defined unilocular or multilocular radiolucencies $(2,7,10)$. It has been reported that asymptomatic cases present unilocular radiolucency, whereas multilocular cases are associated with jaw swelling (15). However, if the lesion contains radiopaque masses in the internal structure, the diagnosis may be calcifying epithelial odontogenic tumor (16).

There are several variants of AF. If dentin is present, the tumor is ameloblastic fibrodentinoma. If dentin and enamel are present, the tumor is called ameloblastic fibro-odontoma (AFO) $(15,17)$. Mitotic figures may be present in AF. The presence of a large number of cells in mitosis and atypical mitosis should expand the differential diagnosis to include malignant entities, like ameloblastic fibrosarcoma (1).

The most appropriate treatment method for AF is still uncertain. A conservative approach is suggested by several authors $(1,10,11)$. However, tumors may recur following surgical removal and progress to malignancy $(7,18,19)$. Thus, long-term follow-up of AF is recommended (18). This report describes an interesting case of AF that affected the maxilla of a young boy and was associated with an unerupted maxillary left first molar.

Correspondence: Profa. Dra. Simone de Queiroz Chaves Lourenço, Avenida das Acácias 150, bl. 01, Apto. 104, Barra da Tijuca, $22776-000$ Rio de Janeiro, RJ, Brasil. Tel: +55-21-3325-1648. Fax:+55-21-2629-9128. e-mail:silourenco@br.inter.net 


\section{CASE REPORT}

In May 2008, an 8 year-old Caucasian boy was referred to the dentist for evaluation of failed eruption of the permanent maxillary left first molar. Physical examination showed a generally healthy child and the medical, surgical, family, and social histories were unremarkable.

Intraoral examination revealed a small painless expansion of the buccal cortical maxillary plate and the first molar was not visualized. The overlying mucosa was intact and normal in color and consistency.

Radiographic examination by means of a panoramic radiograph (Fig. 1A) showed a well-defined unilocular radiolucent lesion in the left maxilla. The crown of the permanent first molar was apparent within the lesion. The second molar was displaced upwards. Computed tomography (CT) scanning confirmed the findings of the panoramic radiograph (Fig. 1B). Based on clinical and roentgenographic findings, a presumptive preoperative diagnosis of dentigerous cyst was done.

Under local anesthesia, the lesion was totally removed through an intraoral approach and protecting the definitive first molar. The enucleated material was sent to the Anatomic Pathology Service of the Antonio Pedro University Hospital, Niterói, RJ, Brazil for histological examination.

Microscopically, the lesion consisted of cords and islands of proliferating odontogenic epithelium. The cords often revealed a double or triple layer of cuboidal cells, resembling the dental lamina. The island showed peripheral rim of columnar similar to the inner enamel epithelium. The center showed a loosely arranged spindle-shaped epithelium identical to stellate reticulum. The epithelial components laid in a myxoid cell-rich stroma with little collagens closely resembling the primitive dental papilla. No hard tooth structures or mitotic images were noted. The histopathological diagnosis was AF (Fig. 2).

After 24 months of follow-up, no recurrence was observed. The first molar was subjected to traction and was aligned with a fixed orthodontic appliance (Fig. 3A). However, radiographic examination revealed that the second molar was impacted to the first molar (Fig. 3B).

\section{DISCUSSION}

AF is a mixed tumor both epithelial and mesenchymal neoplastic proliferation (1). This tumor is usually diagnosed between the first and second decades of life and the majority of cases of occur in the mandible $(2,10,12,15)$. However, few cases of the AF in the maxilla have been reported, as the case presented in this paper $(9,10,13)$.

The clinical manifestations of AF are not specific and the lesion is frequently discovered as an incident finding in a routine radiographic examination, such as cysts and other odontogenic tumors $(1,9)$. Radiographically, the differential diagnosis of the AF must be made with entities such as dentigerous cysts, ameloblastoma, odontogenic keratocysts (9) and fibrosarcoma ameloblastic $(11,18)$.
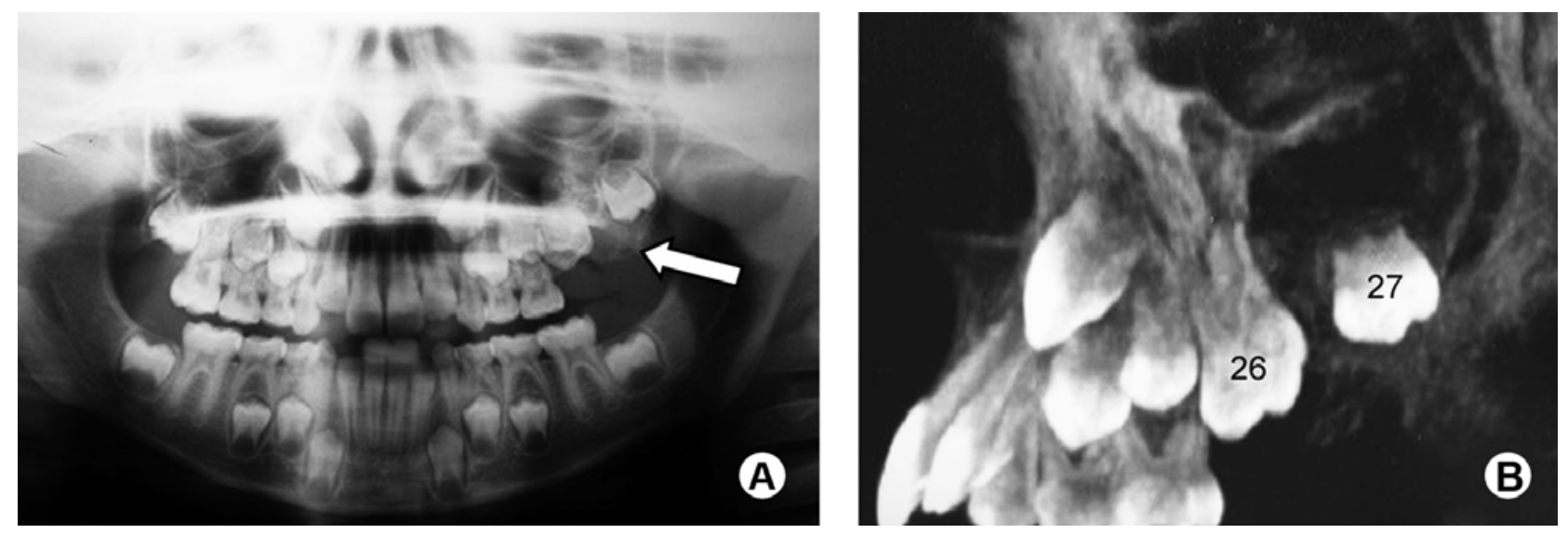

Figure 1. Imaging. A= Initial panoramic film showing a well-circumscribed unilocular radiolucency involving an unerupted permanent maxillary left first molar and displacement of the maxillary left second molar (arrow). B=Computed tomography (CT) scan confirming the findings of the panoramic radiograph. 
Philipsen et al. (17) managed AF by enucleation with careful clinical and radiographic follow-up. AF recurrence may not be true recurrence, but rather a residual lesion due to incomplete enucleation. Some authors believe that an aggressive treatment is not justified $(2,15,17)$. However, Chen et al. (7) reported that patients treated by radical excision experience fewer recurrences compared to those treated conservatively. Those authors found recurrence in 14 of 41 cases. Dallera et al. (2), on the other hand, reported no recurrences for 6 cases with an average follow-up of 15 years. In the present case, the lesion was enucleated with no recurrence at two year.

While uncommon, the possibility of malignant

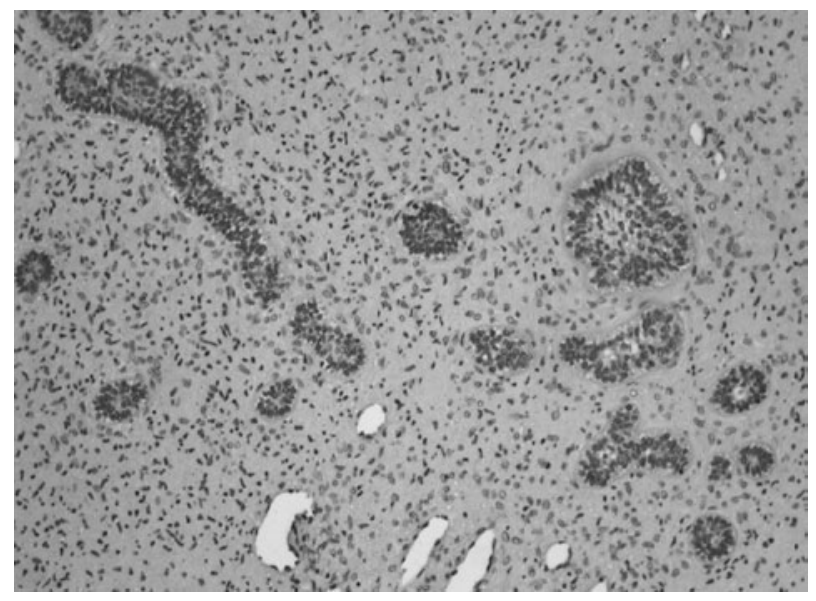

Figure 2. Histological section showing ameloblastic epithelium in cords and island lie in a myxoid cell-rich stroma resembling the primitive dental papilla (HE, $\times 100$ magnification). transformation of AF into ameloblastic fibrosarcoma has been reported by Chen et al. (7) and Kobayashi et al. (18). For those authors, AF showed no signs of malignancy until the second recurrence. Chen et al. (7) reported that the rates of malignant transformation in 5-year and 10-year follow-up were $10.2 \%$ and $22.2 \%$, respectively. However, according to Kousar et al. (19) rapid sarcomatous transformation of an $\mathrm{AF}$ occurred within 6 months.

In the case reported here, the main feature was the failure of eruption of a maxillary first molar. This disturbance may or may not be associated with a pathology, such as AF. Thus, this case emphasizes the importance of careful differential diagnosis in dentistry, while reporting a rare lesion and its atypical location.

\section{RESUMO}

Fibroma ameloblástico é um tumor odontogênico benigno relativamente raro, em que ambos os componentes epiteliais e ectomesenquimais são neoplásicos. Menino de oito anos de idade, branco, foi encaminhado ao dentista para avaliar a falha na erupção do primeiro molar maxilar do lado esquerdo. A radiografia panorâmica revelou imagem radiolúcida, unilocular, bem circunscrita, envolvendo o primeiro molar permanente maxilar esquerdo incluso. A lesão foi enucleada e o material encaminhado para avaliação histopatológica. Microscopicamente, era composta de ilhas e cordões de epitélio odontogênico num estroma mixóide rico em células, que se assemelhava à papila dentária, com diagnóstico histopatológico de fibroma amelobástico. Após 24 meses de acompanhamento, nenhuma recorrência foi observada e o primeiro molar permanente maxilar irrompeu espontaneamente através da mucosa bucal e foi alinhado com aparelho ortodôntico fixo. Esse caso enfatiza a importância do cuidadoso diagnóstico diferencial das lesões orais intra-ósseas e relato de lesão rara e sua localização atípica.
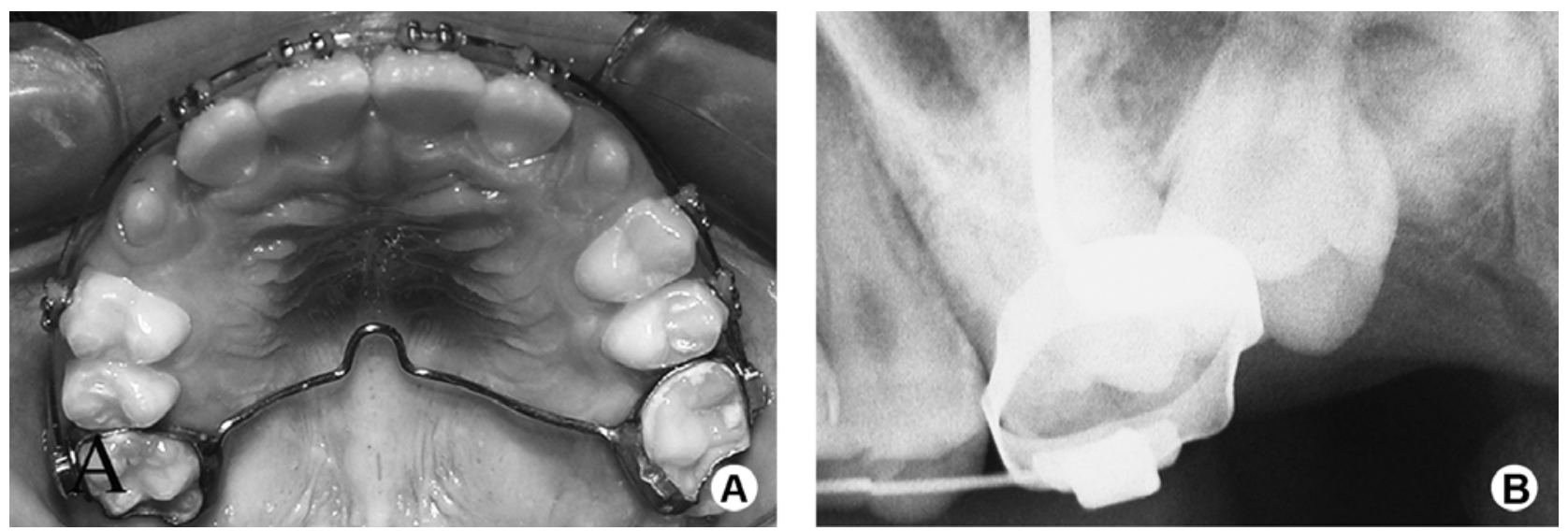

Figure 3. Follow-up. A= Image showing tracioned and aligned the maxillary left first molar with the fixed orthodontic appliance. $\mathrm{B}=$ Periapical film showing that the second molar is impacted against the first molar. 


\section{ACKNOWLEDGEMENTS}

The authors would like to thank the Brazilian Federal Agency for Support and Evaluation of Graduate Education (CAPES) for the financial support.

\section{REFERENCES}

1. Barnes L, Eveson JW, Reichart PA, Sidransky P (Editors). Pathology and genetics of tumours of the head and neck: World Health Organization classification of tumours: International Histological Classification of Tumors. 3rd ed. Lyon: IARC Press, 2005.

2. Dallera P, Bertoni F, Warchetti C, Bacchini P, Campobassi A. Ameloblastic fibroma: A follow-up of six cases. Int J Oral Maxillofac Surg 1996;25:1999-2202.

3. Tawfik MA, Zyada MM. Odontogenic tumors in Dakahlia, Egypt: analysis of 82 cases. Oral Surg Oral Med Oral Pathol Oral Radiol Endod 2010;109: e97-e73.

4. Osterne RLV, Brito RGM, Alves APNN, Cavalcante RB, Souza FB. Odontogenic tumors: A 5-year retrospective study in a Brazilian population and analysis of 3406 cases reported in the literature. Oral Surg Oral Med Oral Pathol Oral Radiol Endod 2011;111:474-481.

5. Ebenezer V, Ramalingam B. A cross-sectional survey of prevalence of odontogenic tumours. J Maxillofac Oral Surg 2011 [Epub ahead of print. DOI: 10.1007/s12663-011-0170-8].

6. Mosby EL, Russell D, Noren S, Barker BF. Ameloblastic fibroma in a 7-week-old infant: a case report and review of the literature. J Oral Maxillofac Surg 1998;56:368-372.

7. Chen Y, Li TJ, Yi, SF. Ameloblastic fibroma and related lesions: a clinicopathologic study with reference to their nature and interrelationship. J Oral Pathol Med 2005;34:588-595.

8. McGuinness NJ, Faughan T, Bennani F, Connolly CE. Ameloblastic fibroma of the anterior maxilla presenting as a complication of tooth eruption: a case report. J Orthod 2001;28:115-117.

9. López RAG, Ortega L, Corchón MAG, Sández AB. Ameloblastic fibroma of the mandible: report of the two cases. Med Oral 2003;8:150-153.

10. Dimitrakopoulos I, Psomaderis K, Zaramboukas T. Ameloblastic fibroma of the mandible associated with root resorption and unerupted teeth: a case report. Quintessence Int 2008;39:523-527.

11. Kim SG, Jang HS. Ameloblastic fibroma: report of a case. J Oral Maxillofac Surg 2002;60:216-218.

12. Pitak-Arnnop P, Chaine A, Dhanuthai K, Bertrand JC, Bertolus C Extensive ameloblastic fibroma in an adolescent patient: a case report with a follow-up of 4 years. Eur J Dent 2009;3:224-227.

13. Nelson BL, Folk GS. Ameloblastic Fibroma. Head and Neck Pathol 2009;3:51-53.

14. Canger EM, Çelenk P, Yenisey M, Odyakmaz SZ. Amelogenesis imperfecta, hypoplastic type associated with some dental abnormalities: a case report. Braz Dent J 2010;21:170-174

15. Chen Y, Wang JM, Li TJ. Ameloblastic fibroma: A review of published studies with special reference to its nature and biological behavior. Oral Oncol 2007;43:960-969.

16. Deboni MCZ, Naclério-Homem MG, Pinto Junior DC, Traina AA, Cavalcanti MGP. Clinical, radiological and histological features of Calcifying epithelial odontogenic tumor: case report. Braz Dent J 2006,17:171-174.

17. Philipsen HP, Reichart PA, Praetorius F. Mixed odontogenic tumors and odontomas. Considerations on interrelationship. Review of the literature and presentation of 134 new cases of odontomas. Oral Oncol 1997;33:86-99.

18. Kobayashi K, Murakami R, Fuji T, Hirano A. Malignant transformation of ameloblastic fibroma to ameloblastic fibrosarcoma: case report and review of the literature. J CranioMaxillofac Surg 2005;33:352-355.

19. Kousar A, Hosein MM, Ahmed Z, Minhas K. Rapid sarcomatous transformation of an ameloblastic fibroma of the mandible: Case report and literature review. Oral Surg Oral Med Oral Pathol Oral Radiol Endod 2009;108;e80-e85. 